\title{
The Effects of Platelet-Rich Plasma on CTGF Produced by Fibroblasts in Hypertrophic Scars
}

\author{
Abd-El-Rahem TA ${ }^{(1)}$, Shaker OG ${ }^{(2)}$, Hassan AR ${ }^{(3)}$, Abd-El- Hady RA ${ }^{(4)}$. \\ (1) professor of Dermatology, STDs and andrology department, Faculty of Medicine \\ Fayoum University. \\ (2)professor of biochemistry , Faculty of Medicine Cairo university. \\ (3)lecturer of Dermatology, andrology and STDs, Faculty of Medicine Fayoum \\ University. \\ (4) Department of Dermatology, Faculty of Medicine Fayoum University. \\ Corresponding author: prof .Talal A. Abd-ElRaheem \\ E-mail address: talasam@yahoo.com \\ Tel:01006600360 \\ Fax: +2084636583
}

\section{ABSTRACT}

Hypertrophic scars are human dermal fibroproliferative disorder that occur following trauma, inflammation, surgery and burns. Connective Tissue Growth Factor (CTGF) is a cysteine-rich mitogen peptide that binds heparin and is secreted by fibroblasts after activation with Transforming Growth Factor beta (TGF $\beta$ ). Platelet-Rich Plasma (PRP) may serve as a source of different growth factors to induce fibrosis in hypertrophic scars.

20 patients with hypertrophic scars in the age group $(16-31)$ years were included in this study with 20 normal volunteers, PRP was injected in the Hypertrophic scars in each patient. Two punch biopsies were taken from every patient one before and one 13 days after PRP injection into the scars. Two serum samples were taken from every patient one before and one after PRP injection in the scars. One punch biopsy was

\section{Introduction}

Hypertrophic scars are human dermal fibroproliferative disorders that occur following trauma, inflammation, surgery and burns. Hypertrophic taken from each control, one serum sample was taken from each control, CTGF level was measured in both tissue biopsies and serum samples using ELISA.

There is a statistical significant increase serum level of CTGF after injection of PRP among patients (with $\mathrm{p}$ value 0.04), which indicated positive effect of PRP on increasing CTGF levels in serum.

There is a statistical significant increase in tissue level of CTGF after injection of PRP among cases with ( $p$ value 0.03), which indicated positive effect of PRP on increasing CTGF levels in tissue. There is a statistical significant increase in tissue CTGF level after PRP injection between groups of study with ( $\mathrm{p}$-value $<0.001)$.

Key words: Hypertrophic scars, Platelet-Rich Plasma (PRP) and Connective Tissue Growth Factor (CTGF).

scars are raised, erythematous, pruritic, fibrous lesions that typically remain within the confines of the original wound. Hypertrophic scars are caused by excessive collagen synthesis and deposition by fibroblasts.[1] 
Healing of wounds is regulated by several cell types and by a cascade of peptides known as cytokines or growth factors. After an injury, growth factor secretion by platelets and macrophages is induced, and inflammationhealing process is initiated. Transforming growth factors- $\beta$ (TGF- $\beta 1$ ) plays key roles in wound healing.[2]

TGF- $\beta 1$ favors the chemoattraction of monocytes and macrophages, and a combined attraction and proliferation of fibroblasts. Connective tissue growth factor is a cysteine-rich mitogenic peptide that binds heparin and is secreted by fibroblasts after activation with transforming growth factor beta.[3]

\section{Subjects and Methods}

The patient group which included 20 patients with hypertrophic scars 13 females (65\%) and 7 males (35\%). The control group included 20 individuals 13 females (65\%) and 7 males (35\%) with no history of hypertrophic scars. The controls were age and sex matched to the patients. Diagnosis was made on clinical basis. Patients were of both sexes and of different age groups. Two biopsies were taken from each patient from the hypertrophic scar one before PRP injection and the other after 13 days of PRP injection in the scar. One biopsy was taken from each control. The selected area was cleaned with alcohol and $1 \mathrm{cc}$ of Xylocaine was injected subcutaneously. A $2.5 \mathrm{~mm}$ punch biopsy was taken before and after PRP injection in the scar and from the control. Biopsies were kept directly into the refrigerator at $-4 \mathrm{C}$. Biopsies were taken in outpatient clinic of Dermatology, STDs and Andrology department, Fayoum University hospital. Specimens were transported in a frozen state to the biochemistry department Kasr El
In the adult mammal, CTGF functions as a downstream mediator of TGF- $\beta$ action on connective tissue cells, where it stimulates cell proliferation and extracellular matrix synthesis. Platelet-rich plasma (PRP) is an autologous preparation of platelets in concentrated plasma.[4]

Various growth factors are secreted from $\alpha$ granules of concentrated platelets activated by aggregation inducers.[5]

Various studies have proved the clinical applications and results of PRP in the fields of dermatology . PRP has been used to treat acne, scarring, and alopecia. It is also effective for skin rejuvenation and tightening around the eyes.[6]

Aini. Two serum samples were taken from each patient one before PRP injection and the other after 13 days of PRP injection in the scar. One serum sample was taken from each control. $2 \mathrm{cc}$ of venous blood had been collected from the anticubital vein using $21 \mathrm{G}$ sterile $5 \mathrm{ml}$ syringe under complete aseptic conditions. The whole blood sample was collected in plastic tubes. Then the whole blood was subjected $\mathrm{t}$ o a $800 \mathrm{D}$ centrifuge at $500 \mathrm{rpm}$ for $10 \mathrm{~min}$ to separate the plasma from the red and white cells. Serum samples were kept directly into the refrigerator at -4 C. Samples were taken in outpatient clinic of Dermatology, STDs and Andrology department, Fayoum University hospital. Specimens were transported in a frozen state to the biochemistry department Kasr El Aini. Patient received 1 session of autologous intradermal PRP injection. Topical anesthetic cream (Pridocaine) was applied under occlusion $30 \mathrm{~min}$ before the session and then the skin was sterilized by alcohol. The area was injected with $1 \mathrm{ml}$ insulin syringe $0.5 \mathrm{~cm}$ spacing between injection sites according to the scar extent.

\section{Results}


This study was a case control study carried out in Dermatology, STDs and Andrology Department, Fayoum University. Twenty patients with hypertrophic scars were included. Twenty age and sex matched volunteers were included as a control group with no history of hypertrophic scars.

\section{1-Sex in different study groups:}

Males were $35 \%$ of the study group and $65 \%$ were females. There was no statistically significance difference P-value 0.2 between patient and control groups as regards sex distripution indicating that they were properly matched.

\begin{tabular}{|c|c|c|c|c|c|c|}
\hline Variables & \multicolumn{2}{|c|}{$\begin{array}{c}\text { Cases } \\
(\mathrm{n}=20)\end{array}$} & $\begin{array}{c}\text { Control } \\
(\mathrm{n}=20)\end{array}$ & p-value \\
\hline \multicolumn{7}{|c|}{ Gender } \\
\cline { 1 - 5 } Male & 7 & $35 \%$ & 12 & $60 \%$ & \multirow{2}{*}{0.2} & NS \\
\hline Female & 13 & $65 \%$ & 8 & $40 \%$ & & \\
\hline
\end{tabular}

\section{2-Age among different study groups:}

The age of the case group ranged between (16-31 years) with mean $(24.3 \pm 5.7)$. The age of the control group ranged between $(17-28$ years $)$ with mean $(23.8 \pm 5.1)$. There was no statistically significant difference P-value 0.4 regarding age between study groups, which indicates proper matching between case and control groups.

\section{3-Duration of the scar:}

\begin{tabular}{|c|c|c|c|c|c|c|}
\hline \multicolumn{2}{|l|}{ Variables } & \multicolumn{2}{|c|}{$\begin{array}{l}\text { Cases } \\
(\mathrm{n}=20)\end{array}$} & \multicolumn{2}{|c|}{$\begin{array}{l}\text { Control } \\
(\mathrm{n}=20)\end{array}$} & $\begin{array}{c}\text { p- } \\
\text { value }\end{array}$ \\
\hline \multicolumn{7}{|c|}{ Age (years) } \\
\hline Mean /SD & 24.3 & 5.7 & 20.8 & 4.5 & 0.4 & NS \\
\hline
\end{tabular}

The duration of the scar in the case group ranged between (6-24 months) with mean \pm SD (13.4 months \pm 6.6).

\begin{tabular}{|c|c|}
\hline Parameter & Duration of scare (months) \\
\hline Minimum & 6 \\
\hline Maximum & 24 \\
\hline Mean & 13.4 \\
\hline SD & 6.6 \\
\hline
\end{tabular}

Correlation between Serum CTGF level before and after injection of PRP and disease duration among cases: 
There was no statistically significant correlation with p-value $>0.05$ between Serum CTGF level before and after injection of PRP and disease duration among cases.

\begin{tabular}{|c|c|c|c|}
\hline \multirow{2}{*}{$\begin{array}{c}\text { Serum CTGF } \\
\text { level }\end{array}$} & \multicolumn{3}{|c|}{ Disease duration (months) } \\
\cline { 2 - 4 } Before & $\mathbf{r}$ & p-value & Sig. \\
\hline After & 0.11 & 0.6 & NS \\
\hline
\end{tabular}

\section{Correlation between tissue CTGF level before and after injection of PRP and disease duration} among cases:

There was no statistically significant correlation with p-value $>0.05$ between tissue CTGF level before injection of PRP and disease duration among cases, on the other hand there is statistically significant negative correlation with p-value 0.03 between tissue CTGF level after injection of PRP and disease duration among cases which indicated increase in disease duration will associated with decrease in tissue CTGF level after injection.

\begin{tabular}{|c|c|c|c|}
\hline \multirow{2}{*}{$\begin{array}{c}\text { Tissue CTGF } \\
\text { level }\end{array}$} & \multicolumn{3}{|c|}{ Disease duration (months) } \\
\cline { 2 - 4 } & $\mathbf{r}$ & $\mathbf{p}$-value & Sig. \\
\hline Before & -0.34 & 0.1 & NS \\
\hline After & -0.48 & $\mathbf{0 . 0 3} *$ & S \\
\hline
\end{tabular}

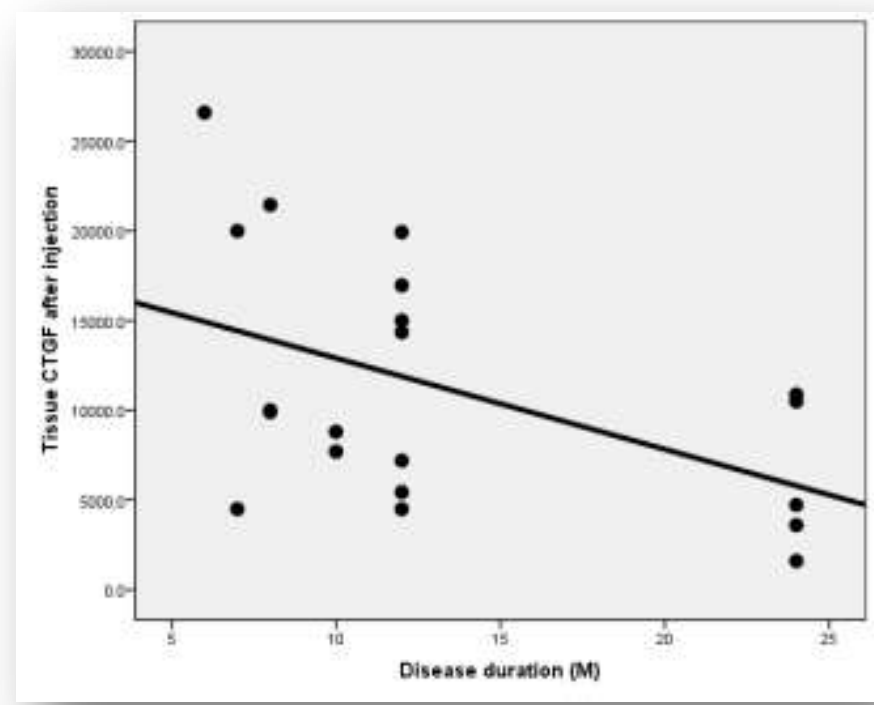

\section{4-Causes of scars:}

Among cases $55 \%$ of them develop scar because of trauma, followed by $20 \%$ caused by infection, then $15 \%$ caused by burn, and finally $10 \%$ caused by operations. 


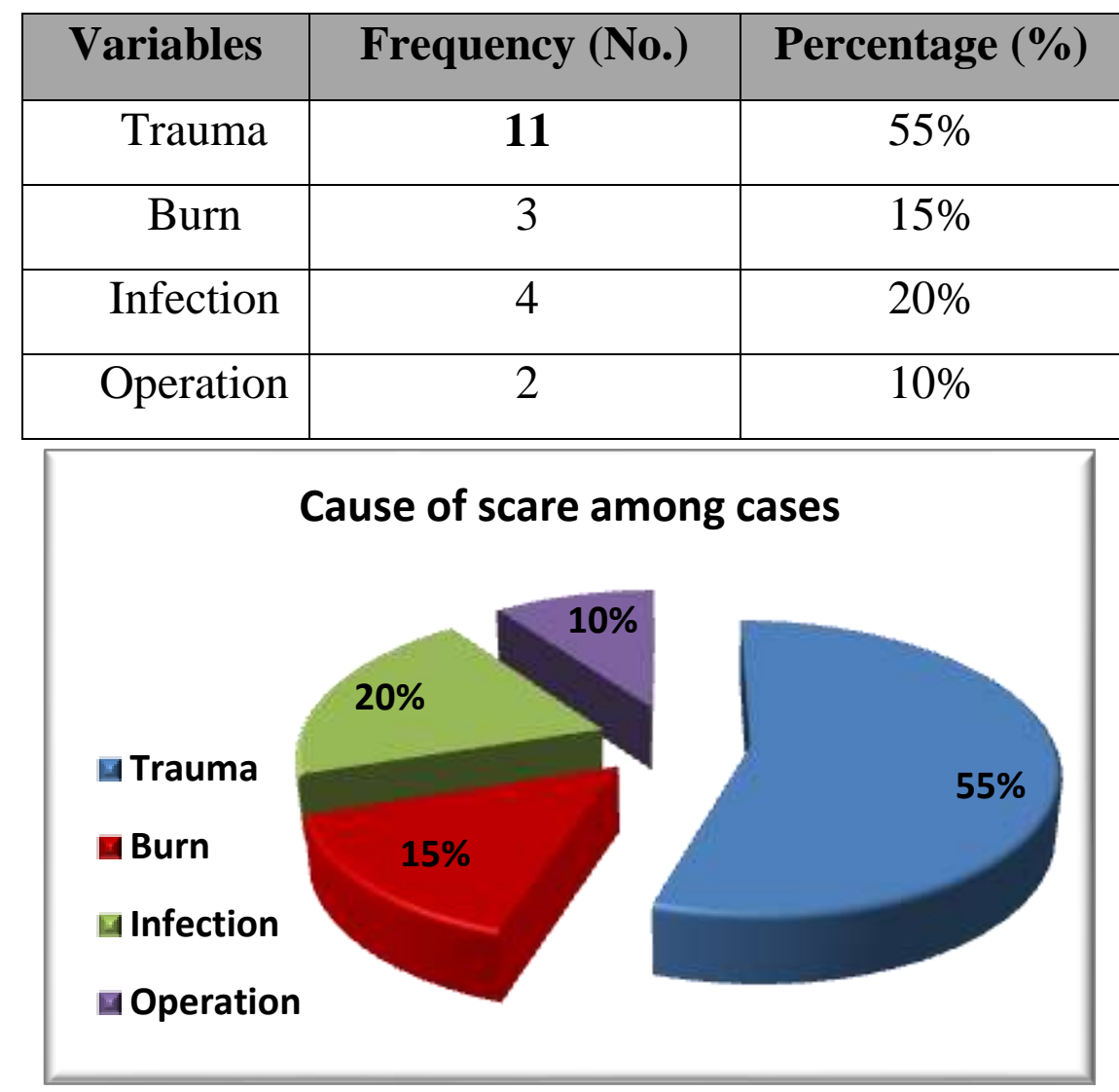

\section{5-Measurment of CTGF in Serum:}

\section{1-Patient Group:}

a-level of CTGF in serum before injection of PRP among cases:

The level of CTGF in serum before injection of PRP Ranged between (105 and 1200)with mean $(342.7 \pm 69.7) \mathrm{ng} / \mathrm{L}$.

\begin{tabular}{|l|l|l|}
\hline \multirow{2}{*}{ CTGF level } & \multicolumn{2}{|l|}{ Cases $(\mathrm{n}=20)$} \\
\cline { 2 - 3 } & Mean & SE \\
\hline Serum (ng/L) & 342.7 & 69.7 \\
\hline
\end{tabular}

b-Level of CTGF in serum after injection of PRP among cases :

The level of CTGF in serum ranged between (1550 and 160) with mean (513 \pm 82.5$) \mathrm{ng} / \mathrm{L}$ which was high.

\begin{tabular}{|c|c|c|}
\hline \multirow{2}{*}{ Serum CTGF level } & \multicolumn{2}{|c|}{ Cases $(\mathrm{n}=20)$} \\
\cline { 2 - 3 } & Mean & SE \\
\hline Serum (ng/L) & $\mathbf{5 1 3 . 9}$ & 82.5 \\
\hline
\end{tabular}




\section{C- Comparisons of serum CTGF level before and after injection of PRP among cases:}

There was statistical significant increase in mean of serum level of CTGF after injection of PRP among cases, which indicated positive effect of PRP on increasing CTGF levels in serum.

\begin{tabular}{|c|c|c|c|c|c|c|}
\hline \multirow{2}{*}{ CTGF level } & \multicolumn{2}{|c|}{ Before $(n=20)$} & \multicolumn{2}{|c|}{ After $(n=20)$} & \multirow{2}{*}{ p-value } & \multirow{2}{*}{ Sig } \\
\hline & Mean & SE & Mean & SE & & \\
\hline Serum (ng/L) & 342.7 & 69.7 & 513.9 & 82.5 & 0.04 & $\mathbf{S}$ \\
\hline
\end{tabular}

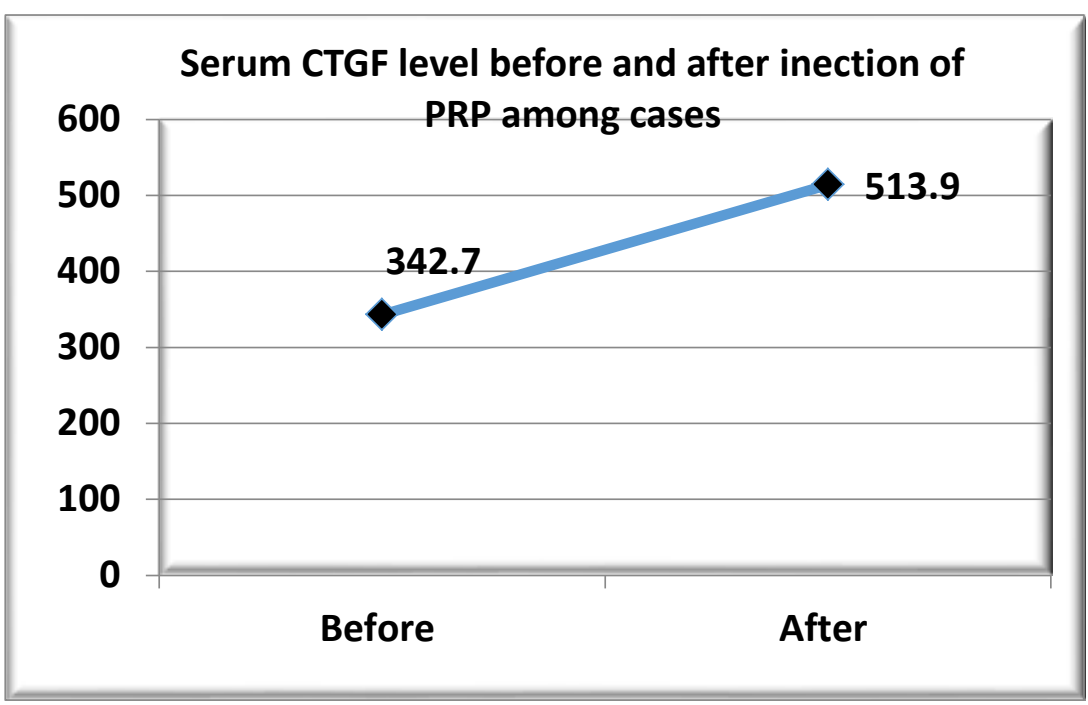

\section{2-control group:}

a-level of CTGF in serum among controls:

The level of CTGF in serum ranged between (200 and 650)with mean (375.3 \pm 33.3$) \mathrm{ng} / \mathrm{L}$.

\begin{tabular}{|l|l|l|}
\hline \multirow{2}{*}{ CTGF level } & \multicolumn{2}{|l|}{ Control $(\mathrm{n}=20)$} \\
\cline { 2 - 3 } & Mean & SE \\
\hline Serum $(\mathrm{ng} / \mathrm{L})$ & 375.3 & 33.3 \\
\hline
\end{tabular}

b-Comparisons of serum CTGF level before injection of PRP in different study groups:

There was no significance difference in serum CTGF level with p-value $>0.05$ between groups of study.

\begin{tabular}{|l|l|l|l|l|l|l|}
\hline \multirow{2}{*}{ CTGF level } & \multicolumn{2}{|c|}{ Cases $(\mathrm{n}=20)$} & \multicolumn{2}{l|}{ Control $(\mathrm{n}=20)$} & \multirow{2}{*}{ p-value } & \multirow{2}{*}{ Sig. } \\
\cline { 2 - 7 } & Mean & SE & Mean & SE & & \\
\hline Serum (ng/L) & 342.7 & 69.7 & 375.3 & 33.3 & 0.7 & NS \\
\hline
\end{tabular}




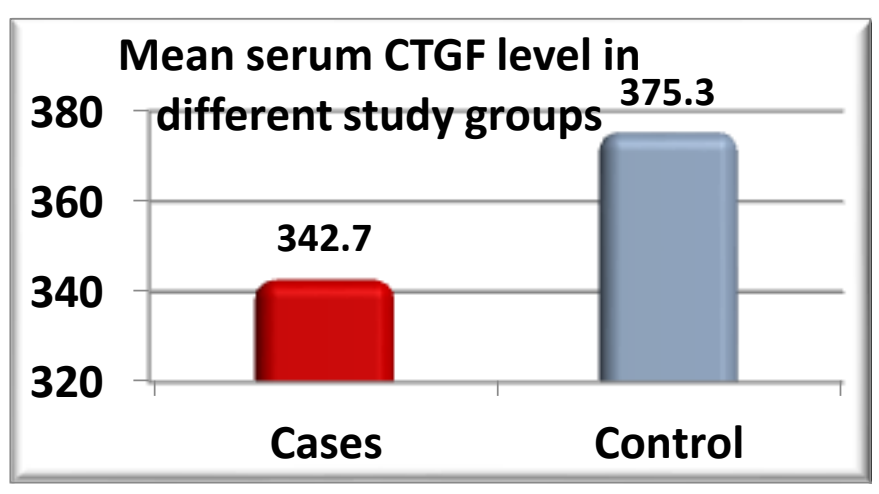

c-Comparisons of serum CTGF level after injection of PRP in different study groups:

There was no significance difference in serum CTGF level after PRP injection with p-value $>0.05$ between groups of study.

\begin{tabular}{|c|c|c|c|c|c|c|}
\hline \multirow{2}{*}{ CTGF level } & \multicolumn{2}{|c|}{ Cases $(n=20)$} & \multicolumn{2}{|c|}{ Control $(n=20)$} & \multirow{2}{*}{$\begin{array}{c}\text { p- } \\
\text { value }\end{array}$} & \multirow{2}{*}{ Sig. } \\
\hline & Mean & SE & Mean & SE & & \\
\hline Serum (ng/L) & 513.9 & 82.5 & 375.3 & 33.3 & 0.1 & NS \\
\hline
\end{tabular}

\section{6- Measurment of CTGF in tissue:}

\section{1- patient group:}

a- level of CTGF in tissue before injection of PRP among cases:

The level of CTGF in tissue ranged between (1750 and 27000) with mean (7979.3 \pm 1580.8$) \mathrm{ng} / \mathrm{L}$.

\begin{tabular}{|l|l|l|}
\hline \multirow{2}{*}{ CTGF level } & \multicolumn{2}{|l|}{ Cases $(\mathrm{n}=20)$} \\
\cline { 2 - 3 } & Mean & SE \\
\hline Tissue (ng/gm) & $\mathbf{7 9 7 9 . 3}$ & 1580.8 \\
\hline
\end{tabular}

b-Level of CTGF in tissue after injection of PRP among cases :

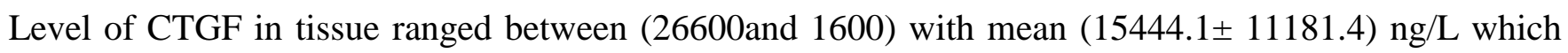
was high.

\begin{tabular}{|l|l|l|}
\hline \multirow{2}{*}{ CTGF level } & \multicolumn{2}{|l|}{ Cases $(\mathrm{n}=20)$} \\
\cline { 2 - 3 } & Mean & SE \\
\hline Tissue (ng/gm) & $\mathbf{1 1 1 8 1 . 4}$ & 15444.1 \\
\hline
\end{tabular}


c-Comparisons of tissue CTGF level before and after injection of PRP among cases:

There was statistical significant increase in mean of tissue level of CTGF after injection of PRP among cases, which indicated positive effect of PRP on increasing CTGF levels in tissue.

\begin{tabular}{|c|c|c|c|c|c|c|}
\hline \multirow{2}{*}{ CTGF level } & \multicolumn{2}{|c|}{ Before $(n=20)$} & \multicolumn{2}{|c|}{ After $(n=20)$} & \multirow{2}{*}{ p-value } & \multirow{2}{*}{ Sig. } \\
\hline & Mean & SE & Mean & SE & & \\
\hline Tissue (ng/gm) & 7979.3 & 1580.8 & 11181.4 & 15444.1 & 0.03 & $\mathbf{S}$ \\
\hline
\end{tabular}

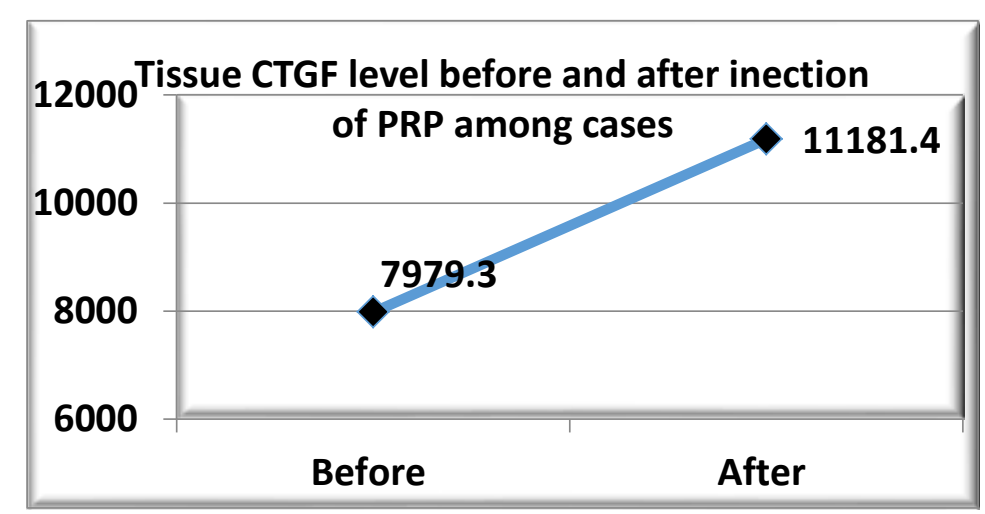

\section{2-control group:}

a- level of CTGF in tissue among controls:

The level of CTGF in tissue ranged between (2300 and 6900) with mean (3859.5 \pm 376.6$) \mathrm{ng} / \mathrm{L}$.

\begin{tabular}{|l|l|l|}
\hline \multirow{2}{*}{ CTGF level } & \multicolumn{2}{|l|}{ Control $(\mathrm{n}=20)$} \\
\cline { 2 - 3 } & Mean & SE \\
\hline Tissue (ng/gm) & 3859.5 & 376.6 \\
\hline
\end{tabular}

b-Comparisons of tissue CTGF level before injection of PRP in different study groups:

There was statistical significant high mean of tissue CTGF level among cases with p-value 0.01.

\begin{tabular}{|c|c|c|c|c|c|c|}
\hline \multirow{2}{*}{ CTGF level } & \multicolumn{2}{|c|}{ Cases $(n=20)$} & \multicolumn{2}{|c|}{ Control $(n=20)$} & \multirow{2}{*}{$\begin{array}{l}\text { p- } \\
\text { value }\end{array}$} & \multirow{2}{*}{ Sig. } \\
\hline & Mean & SE & Mean & SE & & \\
\hline Tissue (ng/gm) & 7979.3 & 1580.8 & 3859.5 & 376.6 & 0.01 & $\mathbf{S}$ \\
\hline
\end{tabular}

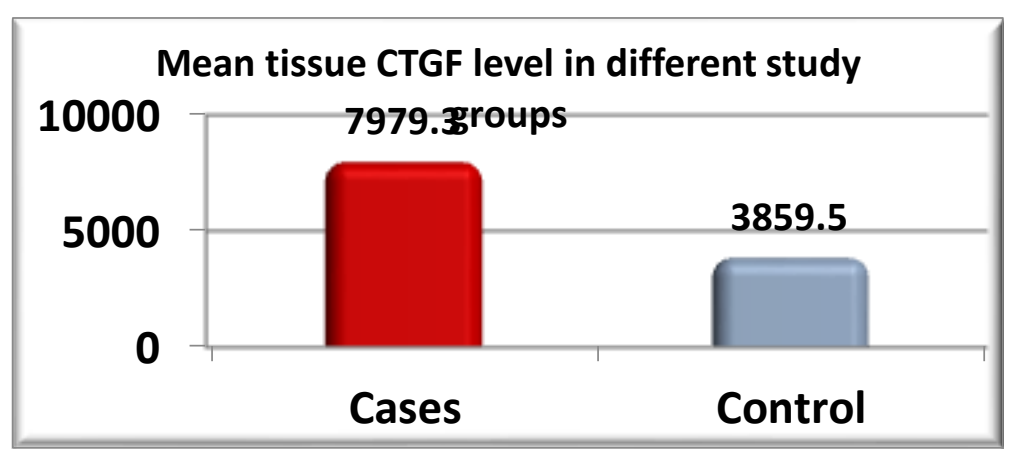


c-Comparisons of tissue CTGF level after injection of PRP in different study groups:

There was statistical significant high mean of tissue CTGF level after PRP injection between groups of study with p-value $<0.001$.

\begin{tabular}{|c|l|l|l|l|l|l|}
\hline \multirow{2}{*}{ CTGF level } & \multicolumn{2}{|l|}{$\begin{array}{l}\text { Cases } \\
(\mathrm{n}=20)\end{array}$} & \multicolumn{2}{l|}{$\begin{array}{l}\text { Control } \\
(\mathrm{n}=20)\end{array}$} & \multirow{2}{*}{ p-value } & Sig. \\
\cline { 2 - 6 } & Mean & SE & Mean & SE & & \\
\hline Tissue (ng/gm) & $\mathbf{1 1 1 8 1 . 4}$ & 1544.1 & 3859.5 & 376.6 & $<\mathbf{0 . 0 0 1}$ & HS \\
\hline
\end{tabular}

\section{Level of CTGF in serum among cases with one spin PRP method:}

Level of CTGF ranged between (1200 and 220) with mean (554.7 \pm 98.8$)$.

Level of CTGF in serum among cases with two spin PRP method:

Level of CTGF ranged between(1550 and 195) with mean (473.2 \pm 136.5$)$.

\section{Comparisons of serum CTGF level in different spins groups:}

There was statistical significant low level of serum CTGF level before injection of PRP among cases which do two spins. Also there is statistical significance increase in serum CTGF level after injection of PRP among patients whose samples treated by two spins, with p-value (0.03, and 0.04 respectively).

On the other hand there was no significance difference in serum CTGF level after injection of PRP between groups under go one or two spins. Also there is no statistical significance change in CTGF level after injection of PRP among patients do one spin with p-value $>0.05$.

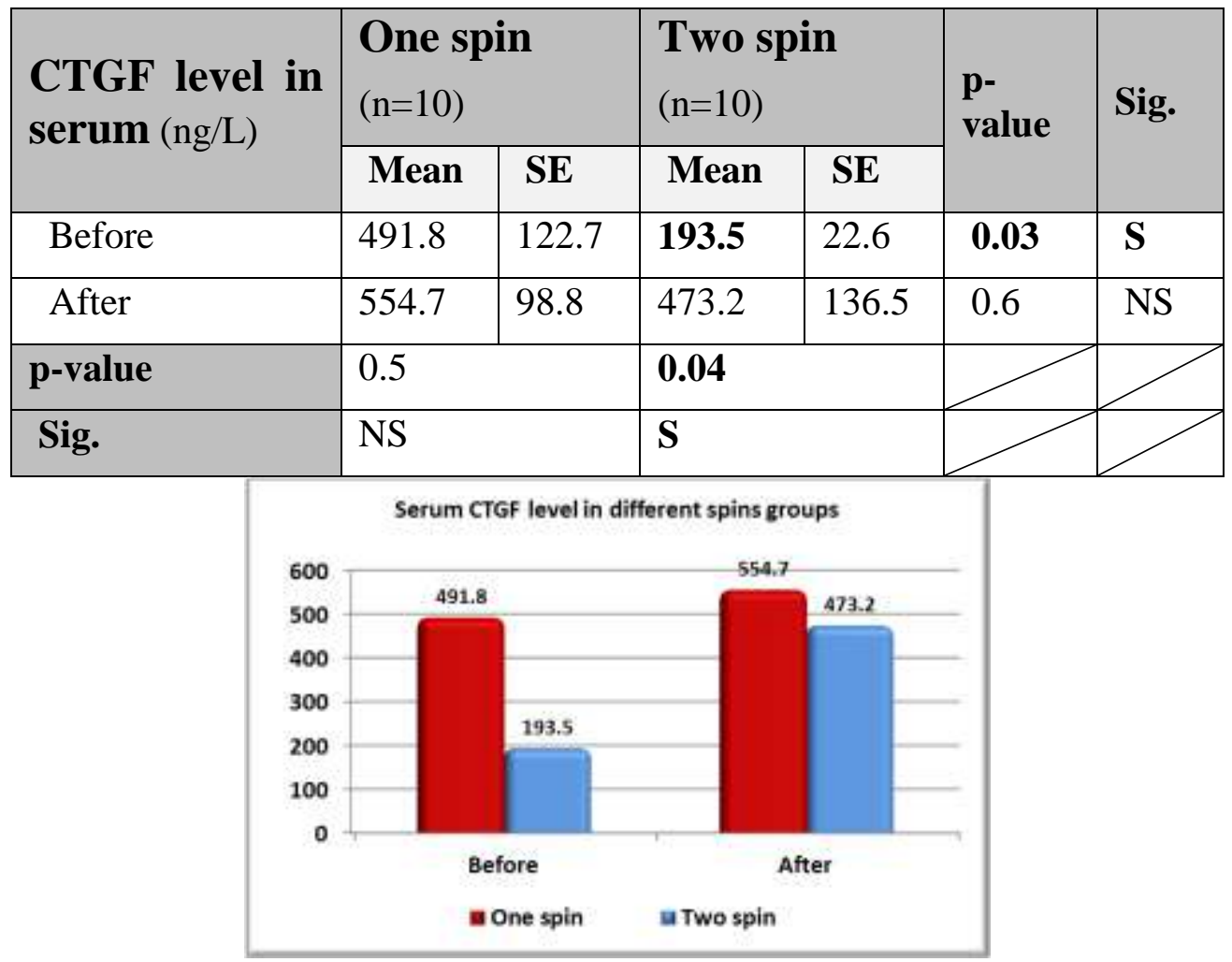




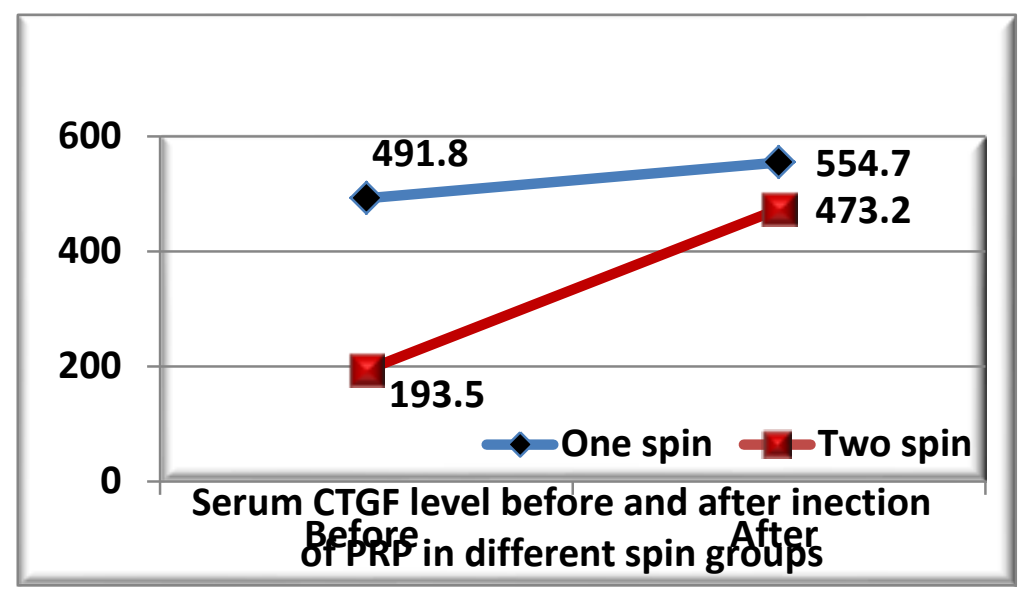

\section{Level of CTGF in tissue among cases which do one spin PRP method:}

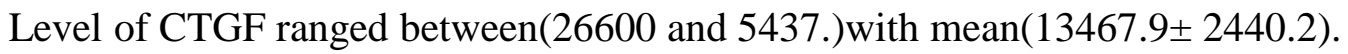

\section{Level of CTGF in tissue among cases which do two spin PRP method:}

Level of CTGF ranged between(19925 and 3600)with mean(8895 \pm 1717.5$)$.

\section{Comparisons of CTGF level in tissue different spins groups:}

There was no statistically significant difference with p-value $>0.05$ in tissue CTGF level before and after injection of PRP between samples undergo one or two spins.

Also there was no statistically significant change with p-value $>0.05$ in tissue CTGF level after injection of PRP in each group of one and two spins.

\begin{tabular}{|l|l|l|l|l|l|l|}
\hline \multirow{2}{*}{$\begin{array}{l}\text { CTGF level in } \\
\text { tissue (ng/L) }\end{array}$} & \multicolumn{2}{|l|}{ One spin (n=10) } & \multicolumn{2}{l|}{ Two spin (n=10) } & \multirow{2}{*}{ p-value } & \multirow{2}{*}{ Sig. } \\
\cline { 2 - 7 } & Mean & SE & Mean & SE & & \\
\hline Before & 833.7 .5 & 2627.9 & 7621 & 1901.6 & 0.8 & NS \\
\hline After & 13467.9 & 2440.2 & 8895 & 1717.5 & 0.1 & NS \\
\hline p-value & 0.09 & & 0.2 & & & \\
\hline Sig. & NS & NS & & & \\
\hline
\end{tabular}

\section{Discussion}

Our study was designed to assess the effect of PRP injection on the level of CTGF in hypertrpphic scars by quantitative method using ELISA technique in both serum samples and tissue biobsies. Also we compared the level of CTGF in hypertrophic scars patients following PRP injection in scars with its level in normal healthy controls.[7] 
There was no agreement among authors regarding whether number of spins in PRP preparation affects platelet concentration or not. Our study reveled that that there was no statistically significant difference with p-value $>0.05$ in tissue CTGF level before and after injection of PRP between samples undergo one or two spins.[8]

In our study two biopsies were taken from each patient from the hypertrophic scars one before PRP injection and the other after 13 days of PRP injection in the scars. One biopsy was taken from each control .Two serum samples were taken from each patient one before PRP injection and the other after 13 days of PRP injection in the scars. One serum sample was taken from each control.

Our data revealed that there was statistical significant increase in mean of serum level of CTGF after injection of PRP among cases ( with $p$ value 0.04 ), which indicated positive effect of PRP on increasing CTGF levels in serum.[9]

\section{Conclusion}

In conclusion, PRP injection in hypertrophic scars results in elevation of both serum and tissue

\section{References}

Abe M, Yokoyama Y and Amano H (2017): Effect of activated human mast cells and mast cell-derived mediators on proliferation, type I collagen production and glycosaminoglycans synthesis by human dermal fibro blasts. Eur $\mathbf{J}$ Dermatol; 12: 340-346.

Badran, M. Abdallah, J. Torres, and F. Tamimi (2017): Platelet concentrates for bone regeneration: Current evidence and future challenges, Platelets, pp. 1-8.
This was consistent with Aghaloo et al. 2018 and Jakse et al. 2015 whose researches showed increased expression of CTGF in serum following PRP injection in androgenic alopescia.[10]

However, our study has 3 limitations. First, our study was a preliminary study. We included only 20 patients who had hypertrophic scars, and the characteristics of 20 hypertrophic scar tissues do not represent all hypertrophic scar tissues. Second, when PRP is activated, the alpha granules release numerous proteins, such as PDGF, TGF- $\beta$, vascular endothelial growth factor (VEGF), epidermal growth factor (EGF), and interleukin (IL)-1.16, 17, 43 Therefore, we cannot conclude that our study outcome was sufficient because PRP includes many other growth factors that might influence the result. Third, our study is an in vivo study. The results of an in vivo study are always influenced by microcellular environments, unlike in vitro studies.[11]

levels of CTGF which indicates its possible role in scars improvement.

Carter K (2016) Growth factors: the wound healing therapy of the future. Wound Care 8:S15-S23.

\section{Choi BH, Im CJ, Huh JY, Suh JJ and Lee SH} (2017): Effect of platelet-rich plasma on bone regeneration in autogenous bone graft. Int $\mathrm{J}$ Oral Maxillofac Surg; 33:56-59.

\section{Ellina O, Chatzigeorgiou $A$ and Kouyanou S} (2017): Extracellular matrix-associated (GAGs, CTGF), angiogenic (VEGF) and inflammatory factors (MCP-1, CD40, IFN- $\gamma$ ) in type 1 diabetes mellitus nephropathy. Clin. Chem. Lab. Med; 50 (1): 167-74. 
Engrav LH, Heimbach DM, Rivara FP, Moore ML, Wang J and Carrougher GJ (2014): 12Year within-wound study of the effectiveness of custom pressure garment therapy. Burns;36:97583.

Gao R, Brigstock DR and Nesbitt JE (2015): Connective tissue growth factor (CCN2) induces adhesion of rat activated hepatic stellate cells by binding of its C-terminal domain to integrin $\alpha(\mathrm{v}) \beta(3)$ and heparan sulfate proteoglycan. J. Biol. Chem; 279 (10): 8848-55. doi: 10.1074/ jbc.M313204200.

Jakse N, Tangl S, Gilli R, Berghold A, Lorenzoni $M$ and Eskici A (2017): Influence of
PRP on autogenous sinus grafts. An experimental study on sheep. Clin Oral Implants Res; 14:578583.

Nyberg P, Xie $L$ and Kalluri R (2015): Endogenous inhibitors of angiogenesis. Cancer Res; 65: 3967-3979.

Rojas, M. D. Pérez del Caz and J. R. Esteban (2017): Evaluation of a new hemostatic agent based on tissue factor in skin grafting procedures, Burns, vol. 43, no. 4, pp. 780-788.

Weibrich G, Hansen T, Kleis W, Buch R and Hitzler WE (2015): Effect of platelet concentration in platelet-rich plasma on periimplant bone regeneration. Bone;34:665-71. 